\title{
Catalytic effects on the non-isothermal oxidation of solid fuels by oxygen: An experimental study
}

Nyombi $\mathrm{A}^{\mathrm{a},{ }^{*}, \text { Williams }} \mathrm{M} \mathrm{R}^{\mathrm{b}}$, Wessling $\mathrm{R}^{\mathrm{a}}$.

${ }^{a}$ Cranfield Forensic Institute - Cranfield University - Shrivenham. Defence Academy of the United Kingdom. SN6 8LA - United Kingdom

${ }^{b}$ Center for Defence Chemistry - Cranfield University - Shrivenham. Defence Academy of the United Kingdom. SN6 8LA - United Kingdom

\section{GRAPHICAL ABSTRACT}

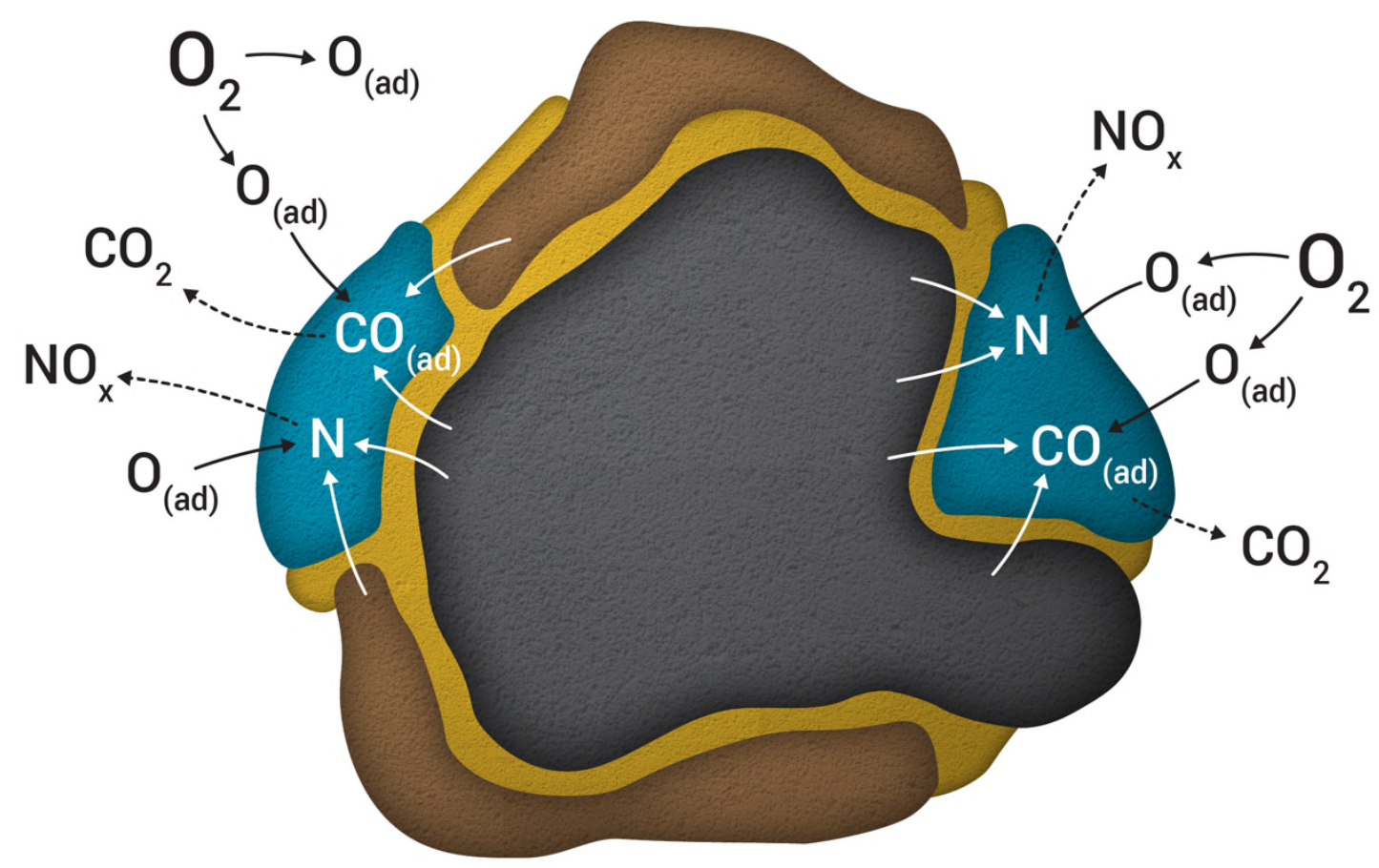

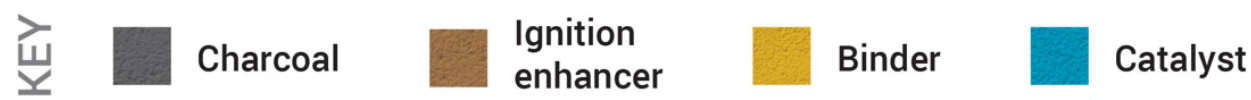

Corresponding author: Antony Nyombi

Email address: a.nyombi@,cranfield.ac.uk

Cranfield University - Shrivenham. SN6 8 LA 


\title{
HIGHLIGHTS
}

The reactivity of $\mathrm{Pd}-\mathrm{Sn} /$ alumina treated and untreated solid fuels were compared. With catalyst treatment;

- $\mathrm{CO}$ emissions factors reduced by $87 \%$,

- Reduced $\mathrm{CO} / \mathrm{CO}_{2}$ ratio by 7 -fold

- Increased combustion efficiency by $60 \%$,

- Increased free active sites on solid fuel surfaces and

- Reduced the temperature for release of NOx emissions

\begin{abstract}
The role played by catalysts in solid fuel reactivity towards oxygen as a viable method for reducing toxic combustion emissions was studied. Catalyst (1wt\% Pd-Sn/alumina) treated, and untreated solid fuels were analysed using thermogravimetric analysis/differential scanning calorimetry (TGA/DSC) coupled with a gas detection system at heating rates $20-$ $40{ }^{\circ} \mathrm{C} / \mathrm{min}$ and airflow rates $30-100 \mathrm{ml} / \mathrm{min}$. The relative $\mathrm{CO}$ emission factors, $\mathrm{NO}_{\mathrm{x}}, \mathrm{CH}_{4}$, energy output, and combustion efficiency were determined as well as the activation energies (Ea) and pre-exponential factors (A) for the oxidation of the solid fuels. Results showed that the catalyst treatment enhanced the energy output by more than $22 \%$ and reduced $\mathrm{CO}$ emission factors by up to $87 \%$. The temperature for release of nitrogen compounds was considerably reduced; however, the amounts produced were not impacted. The combustion efficiency was also improved by up to $60 \%$. In terms of reactivity, catalyst treatment lowered the Ea for oxidation especially at $0.2 \leq \alpha \leq 0.8$. Catalyst treated samples had more free active sites on their surface, which decreased at temperatures $>500{ }^{\circ} \mathrm{C}$ possibly due to thermal deactivation of the catalyst. This is a viable method for minimising toxic emissions from solid fuel combustion and enhancing energy output for domestic and industrial applications.
\end{abstract}

\section{KEYWORDS}

Solid fuels; $\mathrm{CO} / \mathrm{CO}_{2} ; \mathrm{NO}_{x}$; combustion efficiency; catalyst 


\section{INTRODUCTION}

Solid fuels (coal, lump charcoal, and charcoal briquettes) are extensively used for home and recreational cooking applications. Due to insufficient oxygen availability during combustion, fuel-rich conditions that produce toxic emission are created at mid-to-high temperatures $\left(300-800{ }^{\circ} \mathrm{C}\right)$. The toxic emissions (carbon monoxide, nitrous oxide, etc) from incomplete solid fuel combustion have caused several fatalities and chronic illnesses [1], [2], [3], [4], [5], [6].

To reduce the emissions of toxic gases from solid fuel combustion systems, technologically advanced/improved cookstoves [7], [8], [9], that use forced draft systems, with electric fans [10] and chimneys have been used. These enhance the air circulation around the fuel improving the air-to-fuel ratio hence reducing the combustion emissions, as well as drawing out any released pollutant through the stack. Other stoves use a catalyst layer/mesh just above the solid fuel [11] to oxidise the toxic emissions during combustion while other fix the catalyst mesh in the stack of an improved cookstove [12] for the same purpose.

In domestic heaters and boilers, air-staging/two-stage combustion has been used as an effective way to reduce toxic emissions [13]. This involves supplying secondary air to aid further oxidation of flue gases from primary combustion hence reducing toxic gases [14], [15]. Others use a combination of air staging and catalyst layers [16] in stacks to further oxidise unreacted toxic emissions.

The use of CO detectors/alarms [17] for warning against lethal combustion emissions has been embraced extensively. Some sensors are colorimetric [18], forming colored complexes as the concentrations of pollutants change [19]. Others are electrochemical which work by converting $\mathrm{CO}$ to $\mathrm{CO}_{2}$ that is detected using an electrolyte [20] between a working and a counter electrode. Semi-conductor sensors have been the most used [21], [22], [23] employing transition metal oxides like $\mathrm{SnO}$ combined with other metal oxides.

The above-mentioned methods for reducing combustion emissions work in the postcombustion mode (reducing already released emissions), hence a more robust method that minimises toxic emissions from the source is needed. To develop a unique product that releases reduced toxic gases during cooking operations, this work draws motivation from several studies that were performed to enhance desired products during solid fuel 
pyrolysis/combustion/gasification. These involved the addition of catalysts on solid fuels. Inorganic mineral salts [24] particularly potassium (K) salts [25] decreased the temperature at which maximum degradation occurs. Char yields are also increased upon impregnation of $\mathrm{K}$ [26]. Potassium also reduced torrefaction time by over $28 \%$ [27]. Tungsten carbide ( $\mathrm{W}_{2} \mathrm{C} /$ alumina) [28], molybdenum carbide $\mathrm{Mo}_{2} \mathrm{C} /$ support [29] have been impregnated on biomass as effective hydrodeoxygenation agents of biomass-derived small oxygenates, phenolics and furan derivatives. This method has been used for the selective production of aromatic hydrocarbons from lignocellulosic biomass via catalytic fast-hydropyrolysis by removing sulfur, nitrogen, oxygen, and metals. In another study, waste ashes containing Al, $\mathrm{Ca}, \mathrm{Mg}, \mathrm{Cu}$ and $\mathrm{Fe}, \mathrm{K}, \mathrm{Na}$, and $\mathrm{Zn}$ were impregnated with $10 \% \mathrm{Ni}$ to enhance hydrogenrich gas yield by over $15 \%$ from biomass [30]. Catalyst impregnation works in real-time (in heterogeneous reactions) to effect desired products hence; using such a method will ensure that the cooking products (char) are safer from toxic emissions regardless of where they are used.

The objectives of this study, therefore, were to investigate and quantify the difference in reactivity of catalyst (Pd-Sn/alumina) treated charcoal briquettes (CTCB) in comparison to untreated charcoal briquettes (UTCB), commercial lump charcoal (ComC) and coal in the air (21\% oxygen). Experimental studies were conducted to compare the emission of carbon monoxide, carbon dioxide, nitrogen oxides, and methane as well as the energy released from combustion and the combustion efficiency. All the experiments were carried out at different heating rates $\left(20,25,30\right.$, and $\left.40^{\circ} \mathrm{C} / \mathrm{min}\right)$ and airflow rates $(30,50,80$ and $100 \mathrm{ml} / \mathrm{min})$, with temperatures ranging from $50-800{ }^{\circ} \mathrm{C}$. The difference in reactivities was quantified at different conversion levels of the solid fuels in terms of activation energies, and preexponential factors. This study expands on our previous work [31] in which catalyst impregnation was done on charcoal but the experiments were done isothermally in a tube furnace, yet real-life combustion occurs non-isothermally. Secondly, only CO emissions were quantified, and the temperature range was $300-600{ }^{\circ} \mathrm{C}$, and thirdly, this study uses laboratory manufactured charcoal briquettes similar to products on the market.

\section{MATERIALS \& METHODS}

\subsection{Materials}

The CTCB and UTCB were prepared in the laboratory using in-house recipes developed to maximise the desired product. The recipes contained: (i) charcoal fines $(<400$ 
$\mu \mathrm{m}$ particle size) as the main fuel, wood sawdust ( $<400 \mu \mathrm{m}$ particle size $)$ as an ignition enhancer, and cassava flour as the binder for UTCB (ratio: 20:2:1). (ii) Charcoal fines $(<400$ $\mu \mathrm{m}$ particle size) as the main fuel, wood sawdust ( $<400 \mu \mathrm{m}$ particle size) as an ignition enhancer, cassava flour as the binder and $1 \mathrm{w} \% \mathrm{Pd}-\mathrm{Sn} /$ alumina as the catalyst for CTCB (ratio: 20:2:1:0.25). The charcoal used for these recipes was prepared by laboratory pyrolysis of wood as per our previous method [32]. Appropriate amounts of water were added to the solid components and mixed thoroughly with an auto blender to form a paste that was extruded with a mould, dried and stored for subsequent analysis Figure 1, shows the extruded charcoal briquettes. The ComC and coal used in this study were obtained from sales stores.

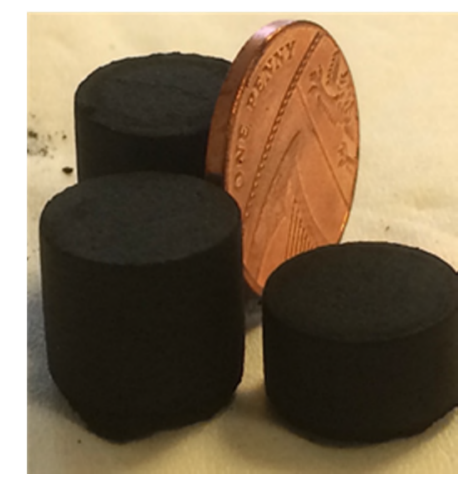

\section{Figure 1: Charcoal briquettes}

\subsection{Experimental set-up}

The experimental set-up is as shown in Figure 2. Four samples were analysed: CTCB, UTCB, ComC, and coal. Dried powdered sample aliquots of 3-5mg were inserted into alumina crucibles and loaded onto the Mettler Toledo TGA/DSC3+. The outlet from the chamber of the TGA/DSC was connected to a MultiRae lite gas analyser calibrated for CO, $\mathrm{CO} 2, \mathrm{NOx}$, and $\mathrm{CH} 4$. The resolution of the analyser is $1 \mathrm{ppm}$ for $\mathrm{CO}, 0.1 \mathrm{ppm}$ for NOx and $100 \mathrm{ppm}$ for $\mathrm{CO}_{2}$. The gas analyser uses a pumped model operation to suck gases on to its sensors at a rate of 2 liters per minute. The MultiRae lite gas analyser was programmed to auto-log data at a rate of a single data point per minute. Combustion experiments were carried out non-isothermally (in triplicate) at $20,25,30$ and $40{ }^{\circ} \mathrm{C} / \mathrm{min}$ heating rates from 50 to 800 ${ }^{\circ} \mathrm{C}$ and airflow rates of $30,50,80$ and $100 \mathrm{ml} / \mathrm{min}$. The proximate analysis was performed as per the methods described elsewhere [33]. Since the gas analyser pump required $2 \mathrm{~L} / \mathrm{min}$ of air, a connection to dry air was added to top-up the total flow during each experiment. The additional air, however, did not affect the concentration of combustion emissions analysed since all the effluents were directed to the gas analyser and were in such low concentrations not to overload the sensors. The gas analyser is equipped with filters at the inlet for volatile 
organic compounds (VOCs), particulate matter and moisture to avoid damage to the sensors and ensuring accuracy and reproducibility of results. Blank runs with air only were performed every after a sample runs for 30 minutes to ensure the MultiRae lite gas analyser was fresh for the next sample.

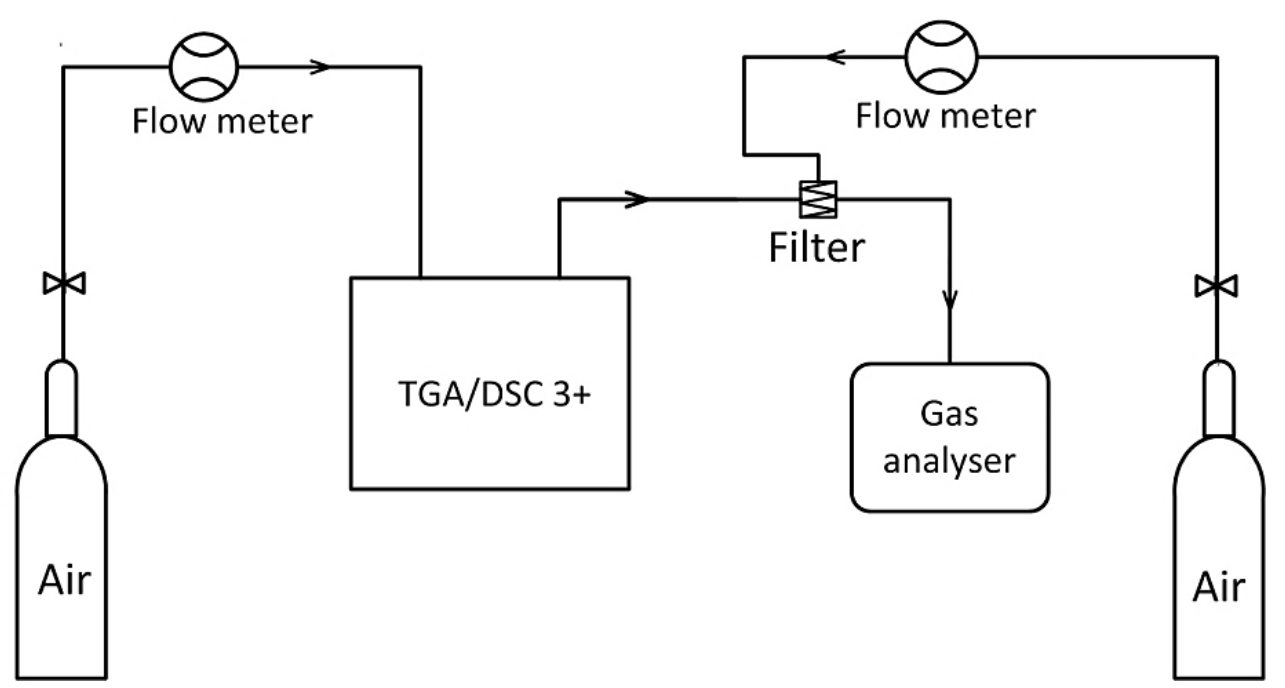

Figure 2: Experimental set-up for the combined TGA/DSC and evolved gas analysis

The computation of $\mathrm{CO}$ emission factors was performed as per the method described in our previous work [34]

Specific surface areas were determined using the ASAP2020 Micromeritics Surface Area and Porosity Analyser instrument. Samples (0.5-1.0 g) were degassed at $200{ }^{\circ} \mathrm{C}$ for 120 minutes. Surface area analysis was done using nitrogen and helium gases.

\section{RESULTS AND DISCUSSIONS}

\subsection{General properties of the solid fuels}

The energy released from the combustion of CTCB, UTCB, ComC, and coal as well as the proximate analysis and specific surface area are shown in Table 1. The energy produced from each solid fuel was calculated from integrals of the exotherm peaks for each run and expressed as $\mathrm{kJ} / \mathrm{g}$. This energy increased with airflow due to increased oxygen availability and decreased with the heating rate. Secondly, CTCB produced up to $6.7 \%$ more energy compared to UTCB, up to $22.3 \%$ more energy compared to ComC and $14.8 \%$ more energy than commercial coal. In general, the high energy output from CTCB was attributed to enhanced combustion facilitated by oxygen adsorbed on the catalyst surfaces. The energy output of fuels analysed was directly linked to their volatile matter (VM) content: the higher 
the VM, the higher the energy released. ComC had the highest specific surface area (SSA) while coal had the lowest $S S A$.

Table 1: Energy released from combustion, proximate analysis and Specific surface area (SSA)

\begin{tabular}{ccccccc}
\hline & $\mathrm{kJ} / \mathrm{g}$ & $\mathrm{M}(\mathrm{wt} \%)$ & $\mathrm{FC}(\mathrm{wt} \%)$ & $\mathrm{VM}(\mathrm{wt} \%)$ & $\mathrm{A}(\mathrm{wt} \%)$ & $\mathrm{SSA}\left(\mathrm{m}^{2} / \mathrm{g}\right)$ \\
\hline $\mathrm{CTCB}$ & $25.33 \pm 0.48$ & $1.52 \pm 0.11$ & $2.71 \pm 0.20$ & $91.8 \pm 0.69$ & $3.88 \pm 0.87$ & 67.3 \\
$\mathrm{UTCB}$ & $23.64 \pm 1.26$ & $1.64 \pm 0.24$ & $3.04 \pm 0.50$ & $91.0 \pm 0.69$ & $4.32 \pm 0.08$ & 78.3 \\
$\mathrm{ComC}$ & $19.70 \pm 0.25$ & $1.09 \pm 0.24$ & $4.8 \pm 0.19$ & $68.15 \pm 1.29$ & $25.96 \pm 1.00$ & 82.2 \\
Coal & $21.57 \pm 1.22$ & $0.95 \pm 0.06$ & $3.54 \pm 0.48$ & $88.58 \pm 0.33$ & $6.93 \pm 0.43$ & 27.0 \\
\hline
\end{tabular}

CTCB-Catalyst treated charcoal briquettes; UTCB-Untreated charcoal briquettes; ComC-Commercial charcoal; M-Moisture content; FC-Fixed carbon; VM-Volatile matter; A-Residual ash; SSA Specific surface area

\subsection{CO emissions trends}

The emission of $\mathrm{CO}$ from the solid fuels took different patterns during the combustion process:

i. CTCB underwent four CO emission stages, Figure 3A. The first positive steep phase between $290-350{ }^{\circ} \mathrm{C}$ (CO values reaching $15 \mathrm{ppm}$ as lowest and $25 \mathrm{ppm}$ as highest) was attributed to release of $\mathrm{CO}$ from pyrolysis as a result of enhanced temperatures in sawdust and cassava binder due to the impregnated metal catalyst. Previous research has proved that metal impurities enhance the combustion temperature during combustion [35]. The second low gradient phase happened between $370-450{ }^{\circ} \mathrm{C}$, in which maximum adsorption of oxygen and $\mathrm{CO}$ onto the catalyst surface took place resulting to maximum oxidation of $\mathrm{CO}$ to $\mathrm{CO}_{2}$ (CO values increased by $2 \mathrm{ppm}$ as lowest and $5 \mathrm{ppm}$ as highest). The third stage happened between $470-500{ }^{\circ} \mathrm{C}$ where the catalyst continuously lost activity due to sintering as temperature increased until most of the charcoal was burnt ( $\mathrm{CO}$ values increased by $5 \mathrm{ppm}$ as lowest and $15 \mathrm{ppm}$ as highest). The last phase occurred between $500-570{ }^{\circ} \mathrm{C}$ when the remaining carbon was decomposed as well as the decay of the accumulated $\mathrm{CO}$.

ii. The UTCB (Figure 3B) had an initial slow release of CO between $290-370{ }^{\circ} \mathrm{C}$ from pyrolysis of hemicellulose, cellulose, and breakdown unstable surface oxide complexes from sawdust and cassava binder ( $\mathrm{CO}$ values reached about $25 \mathrm{ppm}$ ). The second phase was a positive steep gradient from $380-500{ }^{\circ} \mathrm{C}$ attributed to the decomposition of the main char matrix ( $\mathrm{CO}$ values increased by 
$120 \mathrm{ppm}$ as lowest and $230 \mathrm{ppm}$ as highest). The last stage between $530-620^{\circ} \mathrm{C}$ involved the breakdown of any remaining carbon as well as wash-out of accumulated CO.

iii. The ComC (Figure 3C) had an initial slow release of CO between $340-430{ }^{\circ} \mathrm{C}$ from the breakdown of unstable surface oxide functional groups ( $\mathrm{CO}$ values increased to $20 \mathrm{ppm}$ as lowest and $50 \mathrm{ppm}$ as highest). The second positive steep stage from $440-500{ }^{\circ} \mathrm{C}$ corresponded to the decomposition of the main char material (CO values increased by $110 \mathrm{ppm}$ as lowest and $150 \mathrm{ppm}$ as highest). The last stage between $530-700{ }^{\circ} \mathrm{C}$ involved breakdown of any remaining lignin in charcoal as well as decay of accumulated CO.

iv. Coal (Figure 3D) had an initial slow release of $\mathrm{CO}$ between $350-500{ }^{\circ} \mathrm{C}$ from the breakdown of unstable surface oxide complexes (CO values increased to $50 \mathrm{ppm}$ as lowest and $110 \mathrm{ppm}$ as highest). The second $\mathrm{CO}$ release was from $510-590{ }^{\circ} \mathrm{C}$ corresponding to degradation of the main carbon structure (CO values increased by $180 \mathrm{ppm}$ as lowest and $300 \mathrm{ppm}$ as highest). The last stage between $600-790^{\circ} \mathrm{C}$ corresponded to the breakdown of the remaining stable lignin structures and decay of accumulated $\mathrm{CO}$.

v. The emission profiles took a general similar shape for all solid fuels, however, there was a general increase in peak height with an increase in airflow rate. There was also an observed shift in the peak $\mathrm{CO}$ emission values to higher temperatures with a decrease in airflow rates. Similarly, there was a shift of the mass loss profile to higher temperatures (Figure 2 - supporting information) with a decrease in airflow rates. This behavior could be explained by the slow decomposition rates of samples at low airflows creating a shift in the attainment of the peak mass loss and CO emissions. Of all the solid fuels analysed, ComC had the highest ash content. In terms of thermal stability (resistance to decomposition at high temperature), coal $>$ ComC $>$ UTCB $\geq$ CTCB.

Other figures showing the variation of mass loss and $\mathrm{CO}$ emissions at different heating rates and airflows are shown in Figures 1-3 of the supporting information. 

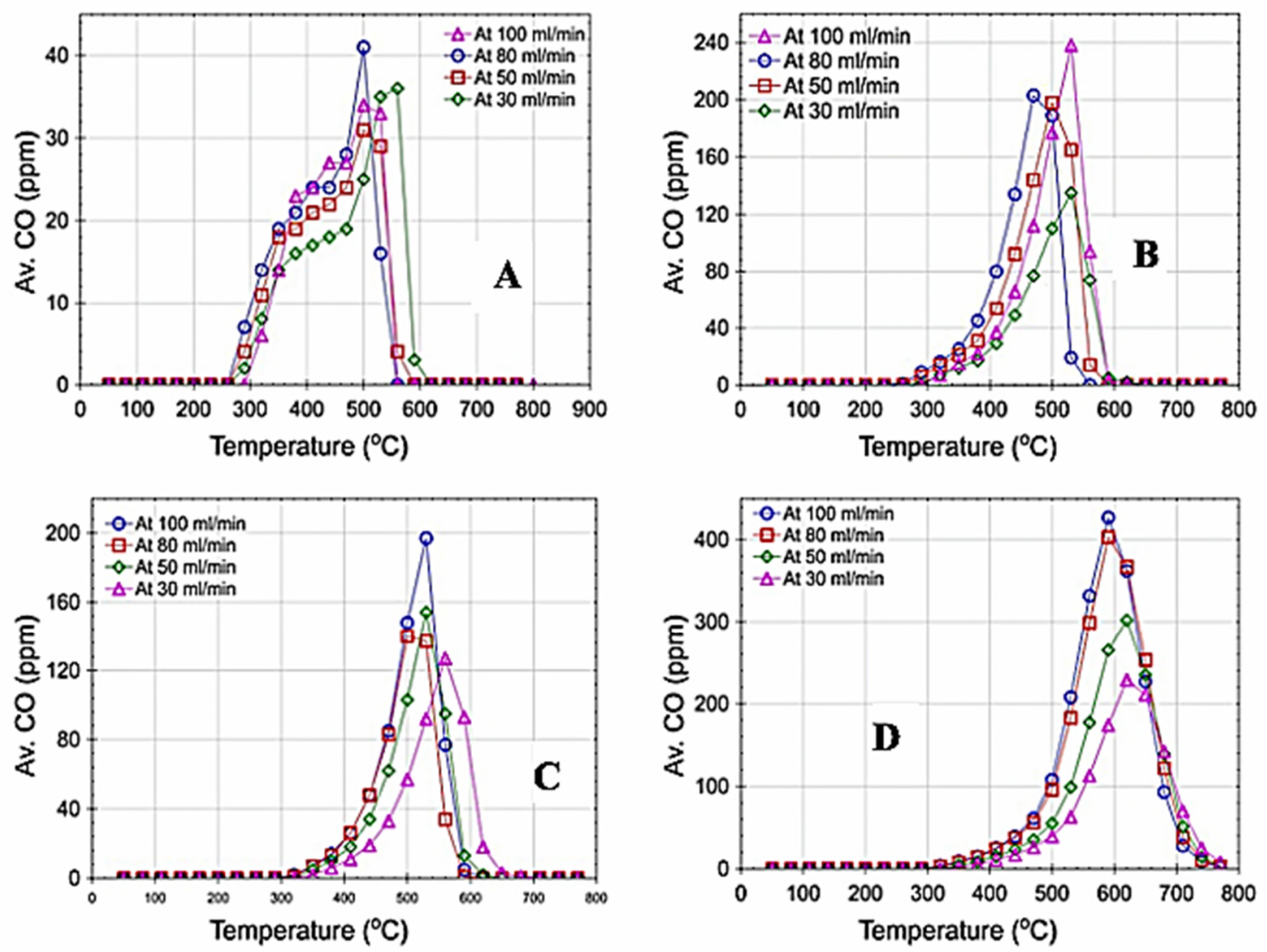

Figure 3: Average CO emissions (Av. CO) at different airflows and $30{ }^{\circ} \mathrm{C} / \mathrm{min}$ heating rate. (A) - CTCB; (B) - UTCB; (C) - ComC; (D) - Coal

Figure 4 shows a summary of the ratios of the $\mathrm{CO}$ emissions (CO emissions from one solid fuel divided by $\mathrm{CO}$ emissions from $\mathrm{CTCB}$ ) from the different solid fuels at $20^{\circ} \mathrm{C} / \mathrm{min}$. We observed that UTCB emitted up-to 8 times more CO than CTCB at its peak/maximum degradation stage. Even at high temperatures $>500{ }^{\circ} \mathrm{C}$ when the catalyst activity had reduced, UTCB still emitted more CO than CTCB. The same analogy applies to ComC and coal. But one point to note is that at the temperatures shown in Figure 4, coal was just in the initial phase of oxidation. Coal's maximum emissions occurred in the range from $570-620^{\circ} \mathrm{C}$ at which point, the average $\mathrm{CO}$ ratio was up to 300 times compared to that of CTCB. 


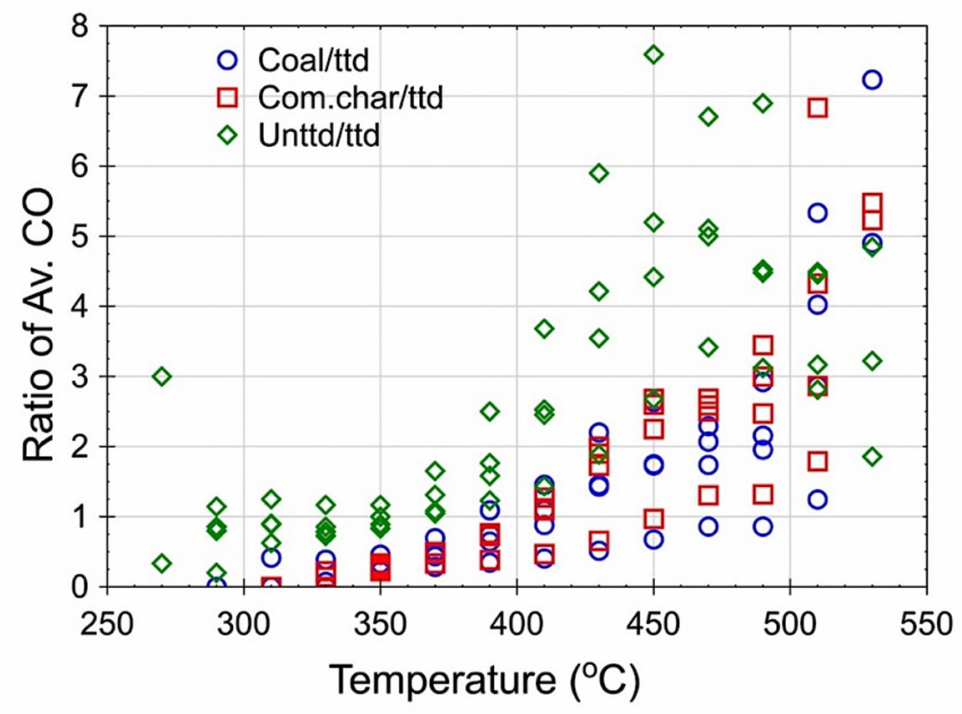

Figure 4: Ratios of Average CO emissions (Av. CO) for Coal/CTCB, ComC/CTCB and UTCB/CTCB at $20^{\circ} \mathrm{C} / \mathrm{min}$. The acronym "ttd" means treated charcoal briquettes or CTCB.

\subsection{CO emission factors}

Figure 5, shows the trend of $\mathrm{CO}$ emission factors (the average emission rate of $\mathrm{CO}$ relative to the initial amount of solid fuel used) calculated for different airflow rates. Three points are shown at each airflow representing different heating rates per sample. Apart from coal at $100 \mathrm{ml} / \mathrm{min}$, all the values for each sample showed no significant differences in $\mathrm{CO}$ emission factors at a single airflow. However, the $\mathrm{CO}$ emission factors increased exponentially with an increase in airflow. Coal had the highest $\mathrm{CO}$ emission factors with a maximum of $155 \mathrm{mg} / \mathrm{g}$ at $100 \mathrm{ml} / \mathrm{min}$ and $20^{\circ} \mathrm{C} / \mathrm{min}$. CTCB had the lowest CO emission factors with $2.8 \mathrm{mg} / \mathrm{g}$ at $30 \mathrm{ml} / \mathrm{min}$ and $20^{\circ} \mathrm{C} / \mathrm{min}$. WU et al. [36], reported that the catalyst treatment of coal tremendously reduced the combustion emissions. The UTCB and ComC emitted almost similar values though the former had slightly higher values (highest of 52 $\mathrm{mg} / \mathrm{g}$ at $100 \mathrm{ml} / \mathrm{min}$ and lowest of $13 \mathrm{mg} / \mathrm{g}$ at $30 \mathrm{ml} / \mathrm{min}$ ). From our previous work [34], the emission factors for ComC were $257.8 \mathrm{mg} / \mathrm{g}$ at $720 \mathrm{ml} / \mathrm{min}, 210.9 \mathrm{mg} / \mathrm{g}$ at $1240 \mathrm{ml} / \mathrm{min}$, $186.6 \mathrm{mg} / \mathrm{g}$ at $1710 \mathrm{ml} / \mathrm{min}$ and $212.7 \mathrm{mg} / \mathrm{g}$ at $2200 \mathrm{ml} / \mathrm{min}$. This trend shows that $\mathrm{CO}$ emission factors were generally decreasing with airflow. However, these values were obtained at isothermal temperatures ranging between $300-600{ }^{\circ} \mathrm{C}$ in a tube furnace and at relatively high airflows. In another study, [31], mechanically impregnated catalysts were used to minimise $\mathrm{CO}$ emissions from charcoal. $\mathrm{CO}$ emissions were reduced but the catalyst lost activity with an increase in temperature. However, that study was also performed at 
isothermal temperatures yet real-life combustion takes place non-isothermally. In the present study, non-isothermal temperatures $\left(50-800{ }^{\circ} \mathrm{C}\right)$ were used with different heating rates $(20-40$ $\left.{ }^{\circ} \mathrm{C} / \mathrm{min}\right)$ and low airflows (30-100 $\left.\mathrm{ml} / \mathrm{min}\right)$.

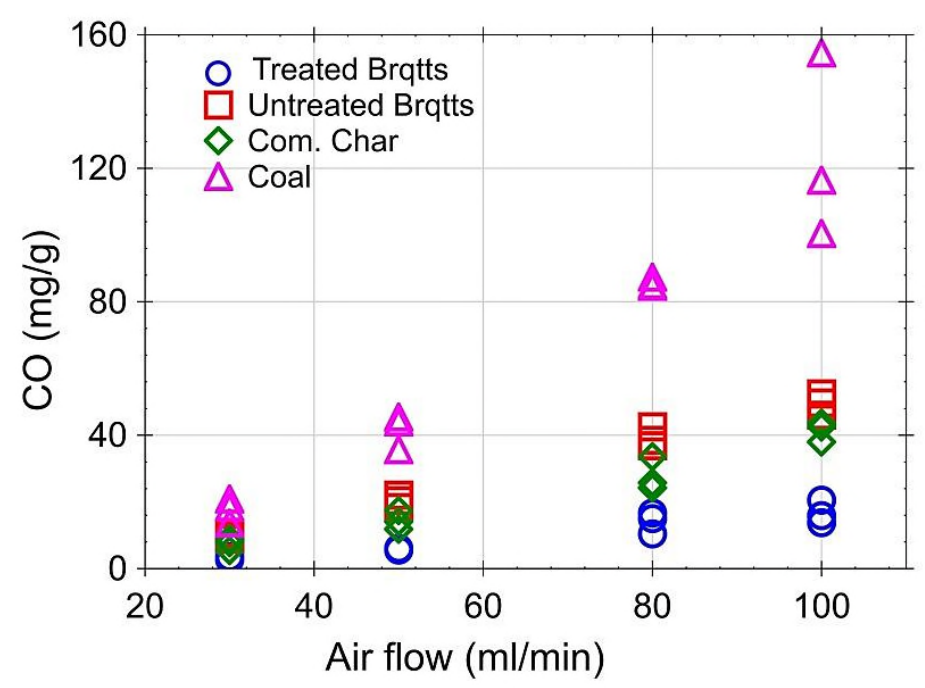

\section{Figure 5: Overall CO emission factors as a function of airflow for Pd-Sn/alumina CTCB, UTCB, ComC, and coal}

\section{4 $\mathrm{CO} / \mathrm{CO}_{2}$ ratio}

The $\mathrm{CO} / \mathrm{CO}_{2}$ ratio is a very important property during combustion of solid fuels. High ratios are usually associated with incomplete combustion. CTCB Figure 6A, showed a slight increase $\mathrm{CO} / \mathrm{CO}_{2}$ between $300-370{ }^{\circ} \mathrm{C}$, reaching the maximum ratio of $\approx 0.12$ with a few spikes close to $\approx 0.23$ and a continuous decline to 0.02 until all the char was burnt above 550 ${ }^{\circ} \mathrm{C}$. The initial increase was due to pyrolysis reactions in sawdust and cassava flour binder as well as the breakdown of unstable carbon oxide surface complexes and other functional groups. The subsequent decline was due to increased oxidation of $\mathrm{CO}$ as a result of strong adsorption of Oxygen and $\mathrm{CO}$ on catalyst surfaces resulting in enhanced reactions forming $\mathrm{CO}_{2}$ until the final decay of accumulated combustion products from the TGA/DSC chamber. UTCB Figure $6 \mathrm{~B}$ showed a slight increase in $\mathrm{CO} / \mathrm{CO}_{2}$ ratio initially to $\approx 0.25$ at $400{ }^{\circ} \mathrm{C}$ which declined gently to 0.1 at $500{ }^{\circ} \mathrm{C}$ and then dropped sharply due to completion of char oxidation and then washing-out of accumulated $\mathrm{CO}$ from the reaction chamber. ComC Figure 6C showed a steep rise in $\mathrm{CO} / \mathrm{CO}_{2}$ ratio to about 0.25 especially at $80 \mathrm{ml} / \mathrm{min}$ followed by a decline until $600{ }^{\circ} \mathrm{C}$. Coal had a continuous increase in $\mathrm{CO} / \mathrm{CO}_{2}$ ratio reaching the highest recorded value in this study of slightly above 0.5 at $600{ }^{\circ} \mathrm{C}$, Figure $6 \mathrm{D}$. In general, coal had more than twice as much of the $\mathrm{CO} / \mathrm{CO}_{2}$ ratio compared to the other solid fuels. The impact 
of airflow on the $\mathrm{CO} / \mathrm{CO}_{2}$ was not significant. In our previous study, [34] the low $\mathrm{CO} / \mathrm{CO}_{2}$ was linked to secondary reactions occurring in the pores of the charcoal promoting the conversion of $\mathrm{CO}$ to $\mathrm{CO}_{2}$ which pores are minimal in coal. This is also reflected by the low specific surface area of coal compared to other solid fuels Table 1. Other figures showing the variation of $\mathrm{CO} / \mathrm{CO}_{2}$ at different heating rates and airflow rates are given in Figures 4-6 of the supporting information.
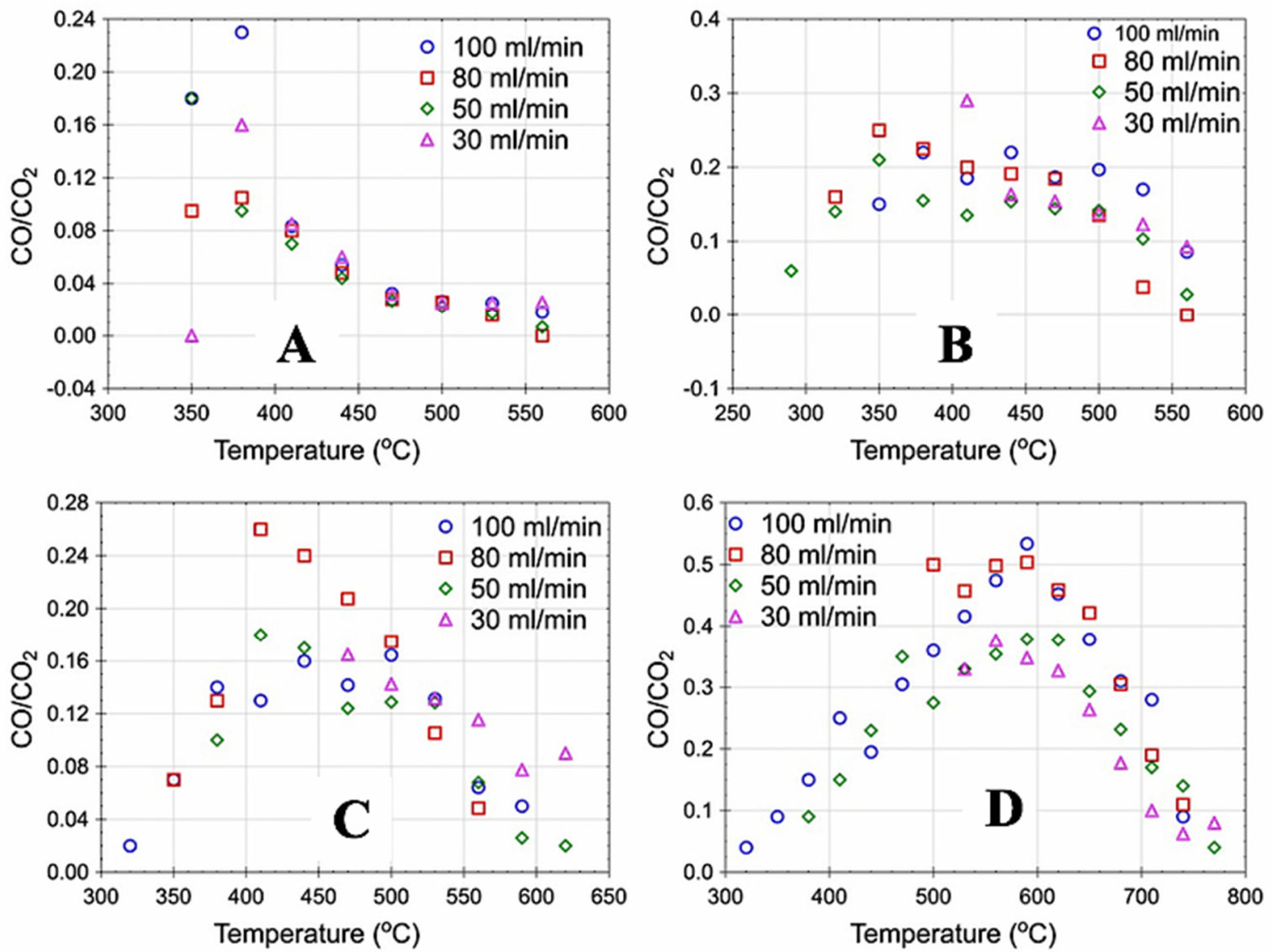

Figure 6: $\mathrm{CO} / \mathrm{CO}_{2}$ ratio at different airflows and $30{ }^{\circ} \mathrm{C} / \mathrm{min}$ heating rate. $\mathrm{A}-\mathrm{CTCB}$; $\mathrm{B}$ UTCB; C - Commercial barbecue charcoal; and D - Commercial coal

The actual $\mathrm{CO} / \mathrm{CO}_{2}$ ratio was also predicted by manipulating experimental data using the relationship analogous to the Arrhenius equation, i.e. $\frac{C O}{C O_{2}}=A_{\alpha} \exp \left(-\frac{B}{T_{\alpha}}\right)$, where A, is a constant independent of temperature and the parameter $\mathrm{B}$, is analogous to an activation energy [37], [38]. We developed a relationship that was used for evaluation of constants B and $A$ at dynamic heating experiments by incorporating a heating rate, $\beta=d T / d t$. Hence, the relationship became; $\left(\frac{C O}{C O_{2}}\right)\left(\frac{d t}{d T}\right)=\left(\frac{d t}{d T}\right)\left(\frac{A_{\alpha}}{\beta}\right) \exp \left(-\frac{B}{T_{\alpha}}\right)$. Introducing natural logarithms and re-arranging, $\operatorname{In}\left[\beta\left(\frac{\mathrm{CO}}{\mathrm{CO}_{2}}\right)\right]_{\alpha, k}=\operatorname{In} A_{\alpha, k}-B_{\alpha, k}\left(\frac{1}{T_{\alpha, k}}\right)$. A plot of the left-hand side against $1000 / \mathrm{T}_{\alpha, k}$ at several $k^{\text {th }}$ heating rates and particular conversion - $\alpha$, yields straight lines Figure 7(A), that were used to determine the constants B and A. In a similar study, Hu et al., [37], expressed the $\mathrm{CO} / \mathrm{CO}_{2}$ ratio with a universal gas constant $(\mathrm{R}=8.314 \mathrm{~J} / \mathrm{mol} . \mathrm{K})$ so that the constants $\mathrm{A}$ and $\mathrm{B}$ could be interpreted as relationships to pre-exponential factors and 
activation energy respectively.
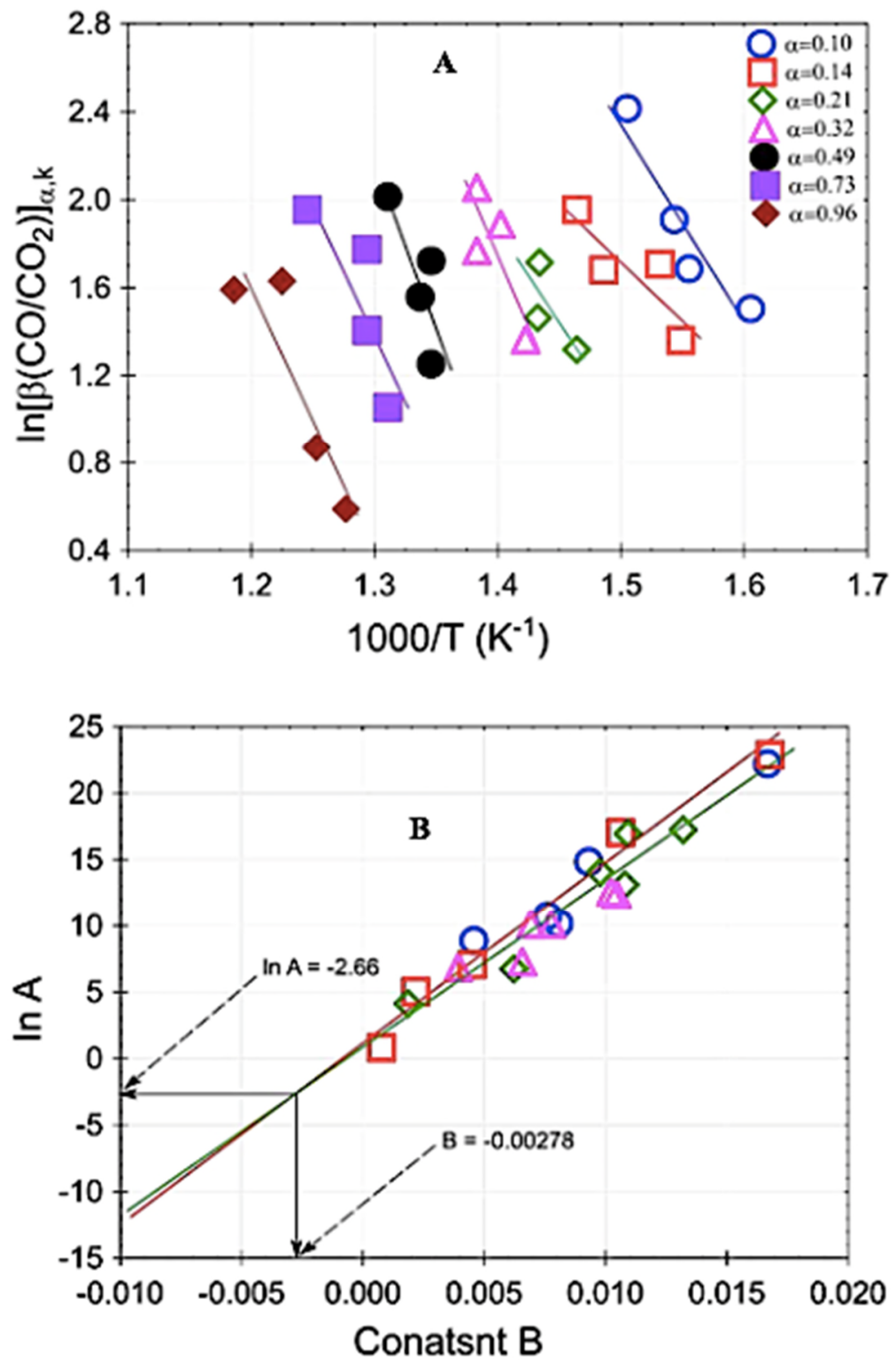

Figure 7: (A) the $\mathrm{CO} / \mathrm{CO}_{2}$ function against 1000/T for determination of $\mathrm{B}$ and $\mathrm{A}$ at different conversions for UTCB. A similar plot was used for CTCB. (B) In A against constant $B$ for CTCB for determination of the true values of constants $A$ and $B$ that were used to predict the $\mathrm{CO} / \mathrm{CO}_{2}$ ratios

Tables 1 and 2 of the supporting information shows the values obtained for the constants $\mathrm{A}$ and $\mathrm{B}$ at different conversions and airflow rates. To obtain the true values that would be used to predict the $\mathrm{CO} / \mathrm{CO}_{2}$ relationships for $\mathrm{CTCB}$ and $\mathrm{UTCB}$, the natural logarithms of A (i.e. InA) were plotted against constants B for the different airflows Figure 7(B). The point of intersection of the respective lines on the plot is the true value of In A and constant B. 
Hence, the general $\mathrm{CO} / \mathrm{CO}_{2}$ relationship obtained for $\mathrm{CTCB}$ was $\mathrm{CO} / \mathrm{CO}_{2}=0.07 \exp (0.00278 / \mathrm{T})$ and $\mathrm{CO} / \mathrm{CO}_{2}=0.2314 \exp (0.00229 / \mathrm{T})$ for UTCB. The predicted equations over-estimates the $\mathrm{CO} / \mathrm{CO}_{2}$ though they are close to the experimental values with minimal error margins. The general trend is a decline in the ratio with an increase in temperature similar to experimental data, and the predicted UTCB values are more than 3fold compared to CTCB. Morin et al., [38], obtained the relationship ${ }^{\mathrm{n}} \mathrm{CO} /{ }^{\mathrm{n}} \mathrm{CO}_{2}=6308.8 \exp (-$ $6724 / \mathrm{T}$ ) for beech stick char obtained by pyrolysis at $923 \mathrm{~K}$ in a fluidised bed reactor. Their ratio showed an increase in $\mathrm{CO} / \mathrm{CO}_{2}$ ratio with temperature; the opposite of what we have obtained for CTCB. However, the ratio depends on the material being investigated [37] among other factors.

\subsection{Mass loss rate}

As shown in Figure 8, the mass-loss rate followed one main segment with a few exceptions. CTCB (A) had the first peak at $350{ }^{\circ} \mathrm{C}$ (maxima at $\approx|3.9| \% / \mathrm{min}$ ) attributed to the breakdown of hemicellulose, and cellulose components in sawdust and cassava binder during pyrolysis forming char. The same peak was observed with UTCB (B) though it was relatively shorter. The decomposition of the main char and lignin components happened at $530{ }^{\circ} \mathrm{C}$ for CTCB, reaching the highest mass loss rate of $|29| \% / \mathrm{min}$ at $80 \mathrm{ml} / \mathrm{min}$ as also observed elsewhere [36]; $|27| \% / \mathrm{min}$ at $100 \mathrm{ml} / \mathrm{min}$ while $30 \mathrm{ml} / \mathrm{min}$ had the lowest peak maxima mass loss rate of $|24| \% / \mathrm{min}$. The completion of degradation of CTCB occurred at $650{ }^{\circ} \mathrm{C}$. UTCB reached a maximum mass loss rate of $|27| \% / \mathrm{min}$ at $100 \mathrm{ml} / \mathrm{min}$ while $30 \mathrm{ml} / \mathrm{min}$ still registered the lowest peak maxima of $23.5 \% / \mathrm{min}$. ComC peak breakdown occurred at 560 ${ }^{\circ} \mathrm{C}$, with $|23| \% / \mathrm{min}$ as the maximum mass loss rate at $100 \mathrm{ml} / \mathrm{min}$ while 50 and $30 \mathrm{ml} / \mathrm{min}$ tied on the peak maxima value of $|20.7| \% / \mathrm{min}$ and its completion of oxidation happened at $710{ }^{\circ} \mathrm{C}$. Coal peak decomposition happened at $620{ }^{\circ} \mathrm{C}$ and it registered the lowest peak mass loss rate among all the samples at $|18| \% / \mathrm{min}$ for $100 \mathrm{ml} / \mathrm{min}$ while its complete degradation occurred at $800^{\circ} \mathrm{C}$. There was a shift in the attainment of the main decomposition peak to higher temperatures with a decrease in airflow rate and an increase in heating rate. Other figures showing the variation of mass-loss rate with temperature are shown in Figures 7-9 of the supporting information. This variation in mass loss rate was attributed to complex reactions, mass transfer, and heat transfer during the char oxidation reactions and the interaction of the char with the metal catalyst [39] in case of CTCB. 



Figure 8: Mass loss rate at different airflows and $30^{\circ} \mathrm{C} / \mathrm{min}$ heating rate. $\mathrm{A}-\mathrm{CTCB}$; $\mathrm{B}$ - UTCB; C - Commercial barbecue charcoal; and D - Commercial coal

\subsection{Kinetic parameters}

Four different heating rates were used for determination of activation energy and preexponential factors with the Friedman and $\mathrm{CO}-\mathrm{CO}_{2}$ model equations. The selection of the best fit was based on the highest regression coefficient possible. The computed values are shown in the subsequent figures and tables. From now onwards, more emphasis will be put on CTCB and UTCB as these have the same recipe only that CTCB has the added $1 \mathrm{w} \%$ PdSn/alumina catalyst. Moreso, the study was focused on comparing catalyst treatment on the oxidation behavior of solid fuels used for cooking purposes. ComC and commercial coal are also compared and discussed intermittently.

\subsubsection{Ea and A based on the conversion rate from mass loss data}

The Friedman equation [40] for determination of Ea and A was developed from $d \alpha / d t=k(T) f(\alpha)$, where $k=A \exp \left(\left(-E_{-} a\right) / R T\right)$, and takes the general form; 
$\frac{d \alpha}{d t}=A_{\alpha} \exp \left(\frac{-E_{\alpha}}{R T_{\alpha}}\right) f(\alpha)$

Introducing a heating rate $\beta=\mathrm{dT} / \mathrm{dt}$ and re-arranging

$\beta_{k}\left(\frac{d \alpha}{d T}\right)_{\alpha, k}=A_{\alpha} \exp \left(\frac{-E_{\alpha}}{R T_{\alpha}}\right) f(\alpha)$

Introducing natural logarithms;

$\operatorname{In}\left[\beta_{k}\left(\frac{d \alpha}{d T}\right)_{\alpha, k}\right]=\operatorname{In}\left[A_{\alpha} f(\alpha)\right]-\frac{E_{\alpha}}{R}\left(\frac{1}{T_{\alpha}}\right)$

where, $f(\alpha)$, is the reaction model function at a particular $\mathrm{k}^{\text {th }}$ heating rate, and $\alpha$ is the conversion. A plot of the left-hand side against $1000 / \mathrm{T}_{\alpha}$ should yield straight lines with gradient, $-\mathrm{E}_{\alpha} / \mathrm{R}$ and intercept $\operatorname{In}\left[\mathrm{A}_{\alpha} \mathrm{f}(\alpha)\right]$, Figure $9(\mathrm{~A})$.
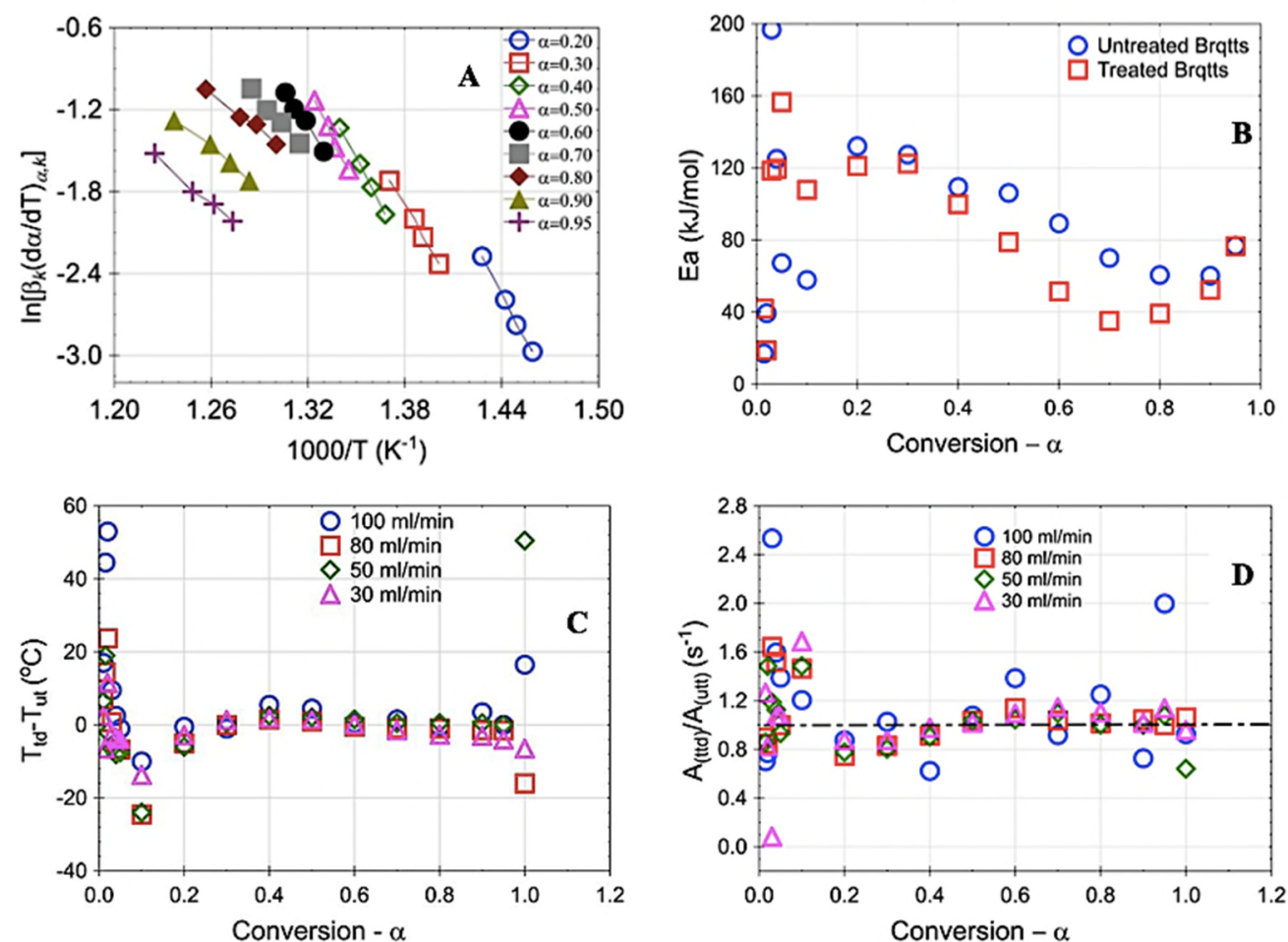

Figure 9: Plots of: (A) Friedman function against 1000/T for data obtained at 100 $\mathrm{ml} / \mathrm{min}$ and different heating rates for CTCB. (B) activation energy for CTCB and UTCB at different conversions. (C) temperature difference between CTCB and UTCB at each degree of conversion for different airflow rates. (D) ratio of pre-exponential factors for CTCB A(ttd) to UTCB A(utt). 
Figure 9(B), show the variation of the energies of the samples at transition states with conversion for UTCB and CTCB. We observed that at low conversions $\alpha<0.1$ (and low temperatures $\mathrm{T}<300^{\circ} \mathrm{C}$ ) the Ea were similar for UTCB and CTCB. This implied that the attainment of the activated complex during CTCB pyrolysis was the same as that of UTCB. At higher conversions $0.2<\alpha<0.8$, the Ea for CTCB continued to be lower than that for UTCB (with statistical significance) due to the catalytic action [36]. However, at high conversions $\alpha>0.9$, the Ea for both solid fuels was almost the same. At this conversion (and high temperatures $\mathrm{T}>500{ }^{\circ} \mathrm{C}$ ), the catalyst continuously lost activity due to thermal sintering and agglomeration [41].

At low temperatures $\left(<300^{\circ} \mathrm{C}\right)$ and lower conversions $(\alpha<0.1)$, the major reactions involved loss of physically and chemically bound moisture and other weakly attached functional groups in endo/exothermic reactions. The addition of a catalyst enhanced the temperature and the exothermicity of the system at lower conversions (with statistical significance) and hence the positive temperature difference Figure 9(C). The temperature difference dT oscillated between negative and positive $\left(0.0 \pm 5^{\circ} \mathrm{C}\right)$ at $0.2<\alpha<1$ but was kept more to the negative side meaning that catalyst treatment lowered the temperature for heterogenous reactions during oxidation.

Assuming both the CTCB and UTCB followed similar reaction mechanism, $f(\alpha)$, at a particular $\mathrm{k}^{\text {th }}$ heating rate, and $\alpha$-conversion, then, the ratio of pre-exponential factors can be determined as follows;

$\frac{A_{T t, \alpha, k}}{A_{U t t, \alpha, k}}=\frac{\left(\frac{d \alpha}{d T}\right)_{T t, \alpha, k}}{\left(\frac{d \alpha}{d T}\right)_{U t t, \alpha, k}} * \exp \left(\left(\frac{E_{\alpha}}{R T_{\alpha}}\right)_{U t t, \alpha, k}-\left(\frac{E_{\alpha}}{R T_{\alpha}}\right)_{T t, \alpha, k}\right)$

where $A_{T t}$ and $A_{U t t}$ are the pre-exponential factors for the CTCB and UTCB at a $\mathrm{k}^{\text {th }}$ heating rate, and conversion- $\alpha$. Using the expression Eqn. 4, the ratio of pre-exponential factors can be deduced at different airflow rates. The same equation was customised for the ComC and coal.

Except for $100 \mathrm{ml} / \mathrm{min}$ airflow whose A ratios kept fluctuating up and below unity (1.0), there were general trends in A ratios for all airflows Figure 9(D). At $\alpha<0.1$, the A ratios were mostly $>1.0$. Between $0.2<\alpha<0.5$, the A ratios were $<1$, while at $0.5<\alpha<0.9$, the A ratios were $>1.0$. At $\alpha>0.9$, the A ratios were generally close to unity (1.0). In regions where A ratios 
were $>1.0$ (which are the majority - with statistical significance), the active sites on the CTCB were more compared to UTCB. This was attributed to adsorptive sites provided by the catalyst and these sites allowed faster and quick turn-over of reactions.

\subsection{Methane and combustion efficiency}

Methane is a common by-product of solid fuel combustion. The quantity obtained of which depends on the $\mathrm{C} / \mathrm{H}$ ratio of the solid fuel and the sensitivity of the analysis system. From all the samples analysed, methane was not detected, possibly due to very low concentration.

The combustion efficiency or selectivity to $\mathrm{CO}_{2}$ is the measure of the total emission of $\mathrm{CO}_{2}$ as a ratio/percentage to the total carbon oxides $\left(\mathrm{CO}_{2} /\left(\mathrm{CO}+\mathrm{CO}_{2}\right)\right)^{*} 100$. This was computed for CTCB, UTCB, ComC, and coal Figure 10. We observed that coal had a decreasing $\mathrm{CO}_{2}$ selectivity due to increased production of high amounts of $\mathrm{CO}$ as temperature increased. The CTCB had low selectivity at temperatures $<400{ }^{\circ} \mathrm{C}$ due to low oxidation of CO. At temperatures $>400{ }^{\circ} \mathrm{C}, \mathrm{CTCB}$ had rapidly increasing selectivity due to enhanced oxygen adsorption on catalyst surfaces that promoted the conversion of $\mathrm{CO}$ to $\mathrm{CO}_{2}$.

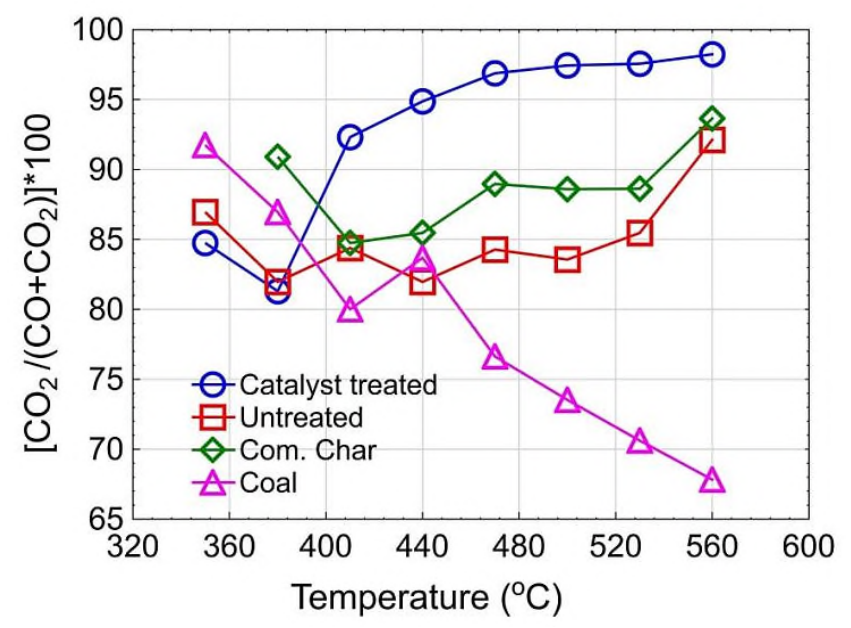

\section{Figure 10: Plot of combustion efficiency for different solid fuels as a function of temperature.}

\subsection{Nitrogen oxides}

The combined nitrogen oxides, commonly known as $\mathrm{NO}_{\mathrm{x}}$, were also analysed in this study and are presented in Figure 11. The NOx arising from the nitrogen in the fuel are termed fuel-nitrogen. Fuel-nitrogen is found in plants, animal proteins, and nitrogen-rich bacteria. Reactions of amines with carboxylic groups or aldehyde groups give rise to 
nitrogenous species present in solid fuels which are typically bound to organic matter. Nitrogen content in solid fuels usually ranges from $0.2 \%$ to $2 \%$ [42]. Biomass fuels usually contain $<1 \%$ nitrogen while coal typically contains $1 \%$ to $2 \%$ of nitrogen with bituminous coals usually containing $1.5-1.75 \%$ and anthracites mostly containing less than $1 \%$ [43].

The $\mathrm{NO}_{\mathrm{x}}$ emissions were observed starting from $440{ }^{\circ} \mathrm{C}$ for $\mathrm{CTCB}$ and above $500{ }^{\circ} \mathrm{C}$ for the rest of the samples. This is because nitrogen forms strong triple bonds that are not easy to break at low temperatures compared to carbon-carbon and carbon-Oxygen bonds. Secondly, catalyst treatment reduced the temperature at which NOx emissions were produced. We observed that except for ComC, the areas under the curves (giving total amount of NOx) were not distinguishable implying that catalyst treatment did not increase the amounts of NOx produced. The low NOx emissions produced by ComC could be related to its low nitrogen content as observed in our previous study [34]. However, in one study [44], it was observed that metal impurities in biomass solid enhanced NOx emissions during combustion.

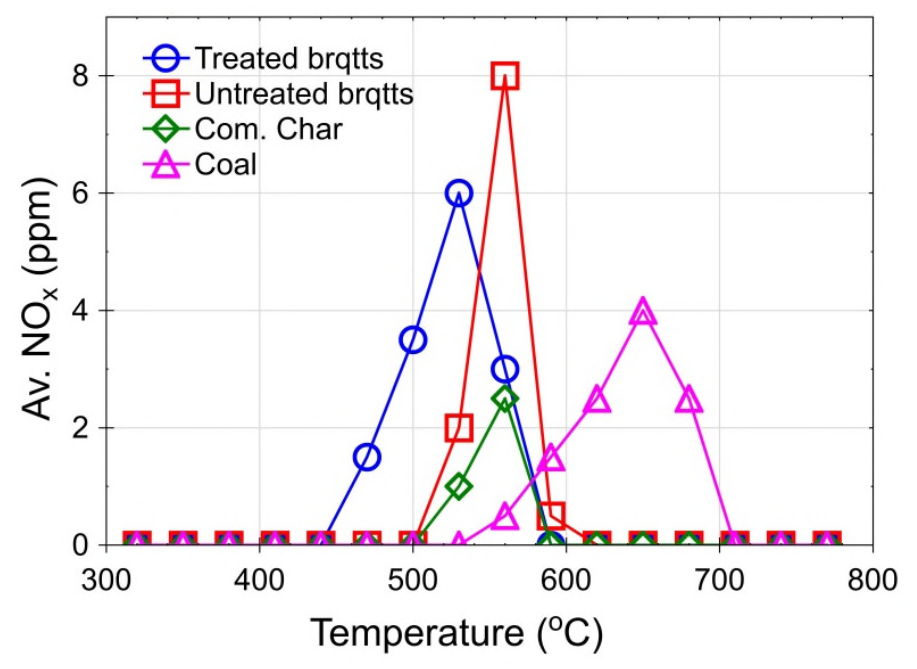

Figure 11: Scatter plot for NOx emissions for different solid fuels

\section{CONCLUSIONS}

The effect of catalyst treatment on solid fuel reactivity in an oxidative environment was studied and quantified experimentally. Two laboratory prepared biomass briquette types: catalyst ( $1 \mathrm{w} \%$ Pd-Sn/alumina) treated charcoal briquettes (CTCB) and untreated charcoal briquettes (UTCB) were studied in addition to commercial charcoal (ComC) and coal. CO emissions and NOx usually affected by oxygen supply and thermal reactivity. To study how these factors affect solid fuels reactivity, non-isothermal thermogravimetric analysis in the air 
(21\% oxygen) coupled with evolved gas analysis with a robust online multi-sensor gas analyser was performed. The outputs from the experiments were used to determine and compare energy output, $\mathrm{CO}$ emission factors, $\mathrm{NOx}$, combustion efficiency, activation energy (from mass loss and $\mathrm{CO}-\mathrm{CO}_{2}$ emissions) as well as pre-exponential factors. It has been demonstrated that catalyst treatment of solid fuels enhanced their energy output by more than $22 \%$ and reduced CO emission factors by $87.1 \%, 63.6 \%$, and $55.6 \%$ compared to coal, UTCB, and ComC respectively. Catalyst treatment lowered the temperature at which NOx emissions were produced but did not affect their quantity. The combustion efficiency was also improved by up to $60 \%$ compared to coal and up to $20 \%$ compared to UTCB and ComC. Treatment of solid fuels with catalyst lowered the activation energy for oxidation especially at $0.2 \leq \alpha \leq 0.8$. CTCB had more free active sites for reactions evidenced by an increased ratio of pre-exponential factors, however, the active sites decreased at temperatures $>500{ }^{\circ} \mathrm{C}$ possibly due to thermal deactivation of the catalyst. Overall, this is a very promising method for minimising toxic emissions from the combustion of solid fuels and enhancing energy output for domestic and industrial applications. However, more research is needed for thermally stable catalysts at high temperatures.

\section{ASSOCIATED CONTENT}

All the data associated with this work is provided in the supporting information document attached. It contains the experimental TG, DTG, relative $\mathrm{CO}$ emission data at different heating rates 20,30 and $40{ }^{\circ} \mathrm{C} / \mathrm{min}$. It also contains tables for constants $\mathrm{A}$ and $\mathrm{B}$ used for predicting $\mathrm{CO} / \mathrm{CO} 2$ ratios for catalyst treated and untreated solid fuels.

\section{ACKNOWLEDGMENTS}

The authors thank the experimental support provided by Adrian Mustey and Karl Norris.

\section{FUNDING}

This work was funded by the Gas Safety Trust (United Kingdom), Boat Safety Scheme (United Kingdom), Katie Haines Memorial Trust (United Kingdom), and Cranfield Forensic Institute (United Kingdom). 


\section{AUTHOR INFORMATION}

\section{Corresponding Author}

A Nyombi

Email: a.nyombi@cranfield.ac.uk

ORCID ID: https://orcid.org/0000-0003-0577-3099

NOMENCLATURE

\section{Acronyms}

ComC Commercial Charcoal

CTCB Catalyst Treated Charcoal Briquettes

DSC Differential Scanning Calorimetry

SSA Specific surface area

TGA Thermogravimetric Analysis

UTCB Untreated Charcoal Briquettes

VOCs Volatile Organic Compounds

\section{Symbols}

$\alpha$

$\beta$

A

$\mathrm{Al}$

$\mathrm{Ca}$

Calcium 


\begin{tabular}{|c|c|}
\hline $\mathrm{CH}_{4}$ & Methane \\
\hline $\mathrm{CO}$ & Carbon monoxide \\
\hline $\mathrm{CO}_{2}$ & Carbon dioxide \\
\hline $\mathrm{Cu}$ & Copper \\
\hline $\mathrm{Ea}$ & Activation energy $(\mathrm{kJ} / \mathrm{mol})$ \\
\hline $\mathrm{Fe}$ & Iron \\
\hline $\mathrm{K}$ & Potassium \\
\hline$k$ & Rate constant $\left(\mathrm{s}^{-1}\right)$ \\
\hline $\mathrm{Mg}$ & Magnesium \\
\hline $\mathrm{Mo}_{2} \mathrm{C}$ & Molybdenum Carbide \\
\hline$n$ & Reaction order \\
\hline $\mathrm{Na}$ & Sodium \\
\hline $\mathrm{NO}_{\mathrm{x}}$ & Nitrogen Oxides \\
\hline${ }^{\circ} \mathrm{C} / \mathrm{min}$ & Degrees centigrade per minute \\
\hline $\mathrm{Pd}$ & Palladium \\
\hline $\mathrm{R}$ & Universal gas constant $(8.314 \mathrm{~J} / \mathrm{mol} . \mathrm{K})$ \\
\hline $\mathrm{Sn}$ & Tin \\
\hline $\mathrm{T}$ & Thermodynamic temperature $(\mathrm{K})$ \\
\hline$t$ & Time \\
\hline$V$ & Char oxidation rate $(\mathrm{mol} / \mathrm{s})$ \\
\hline $\mathrm{W}_{2} \mathrm{C}$ & Tungsten Carbide \\
\hline $\mathrm{Zn}$ & Zinc \\
\hline
\end{tabular}




\section{Sub/superscripts}

$\mathrm{C}_{0} \quad$ Concentration of the gaseous products at the initial temperature

${ }^{\circ} \mathrm{C} \quad$ Degrees centigrade

\section{REFERENCES}

[1] D. Chakraborty, N. K. Mondal, and J. K. Datta, "Indoor pollution from solid biomass fuel and rural health damage: A micro-environmental study in rural area of Burdwan, West Bengal,” Int. J. Sustain. Built Environ., vol. 3, no. 2, pp. 262-271, 2014.

[2] Y. Y. Chen et al., "Suicide by burning barbecue charcoal in England," J. Public Heal. (United Kingdom), vol. 35, no. 2, pp. 223-227, 2013.

[3] N. B. Hampson, C. C. Kramer, R. G. Dunford, and D. M. Norkool, "Carbon Monoxide Poisoning From Indoor Burning of Charcoal Briquets,” JAMA, vol. 271, no. 1, pp. $52-$ 53, Jan. 1994.

[4] C. Winder, "Carbon monoxide-induced death and toxicity from charcoal briquettes," Med. J. Aust., vol. 197, no. 6, pp. 349-350, Sep. 2012.

[5] P. R. Nielsen, A. Gheorghe, and N. Lynnerup, "Forensic aspects of carbon monoxide poisoning by charcoal burning in Denmark, 2008-2012: An autopsy based study," Forensic Sci. Med. Pathol., vol. 10, no. 3, pp. 390-394, 2014.

[6] J. R. Lyness and J. Crane, "Carbon Monoxide Poisoning From Disposable Charcoal Barbeques," Am. J. Forensic Med. Pathol., vol. 32, no. 3, 2011.

[7] N. MacCarty, D. Still, and D. Ogle, "Fuel use and emissions performance of fifty cooking stoves in the laboratory and related benchmarks of performance," Energy Sustain. Dev., vol. 14, no. 3, pp. 161-171., 2010.

[8] M. Njenga et al., "Gasifier as a cleaner cooking system in rural Kenya," Clean. Prod., 
vol. 121, pp. 208-217., 2016.

[9] M. Njenga et al., "Quality of charcoal produced using micro gasification and how the new cook stove works in rural Kenya," Environ. Res. Lett., vol. 12, no. 9, p. art. no. $095001, ., 2017$.

[10] F. Yip et al., "Assessment of traditional and improved stove use on household air pollution and personal exposures in rural western Kenya," Environ. Int., vol. 99, pp. 185-191, 2017.

[11] D. O. Obada, M. Peter, D. M. Kulla, N. O. Omisanya, A. Y. Atta, and D. DodooArhin, "Catalytic abatement of CO species from incomplete combustion of solid fuels used in domestic cooking," Heliyon, vol. 4, no. 8, pp. e00748-e00748, Aug. 2018.

[12] A. D. Paulsen et al., "Gaseous and particulate emissions from a chimneyless biomass cookstove equipped with a potassium catalyst," Appl. Energy, vol. 235, no. October, pp. 369-378, 2018.

[13] K. Nuutinen, J. Jokiniemi, O. Sippula, H. Lamberg, and J. Sutinen, "Effect of air staging on fine particle , dust and gaseous emissions from masonry heaters," Biomass and Bioenergy, vol. 67, pp. 167-178, 2014.

[14] H. Lamberg et al., "Operation and Emissions of a Hybrid Stove Fueled by Pellets and Log Wood," Energy \& Fuels, vol. 31, no. 2, pp. 1961-1968, 2017.

[15] F. Sher, M. A. Pans, T. A. Daniel, C. Sun, and H. Liu, "Experimental investigation of woody and non-woody biomass combustion in a bubbling fluidised bed combustor focusing on gaseous emissions and temperature profiles," Energy, vol. 141, pp. 2069$2080,2017$.

[16] S. Bensaid, F. A. Deorsola, D. Fino, and N. Russo, "After-treatment of household wood-fired stove emissions: From catalyst formulation to full-scale system," Catal. Today, vol. 197, no. 1, pp. 76-89, 2012.

[17] M. Zhi, A. Koneru, F. Yang, A. Manivannan, J. Li, and N. Wu, "Electrospun $\mathrm{La} 0.8 \mathrm{Sr} 0.2 \mathrm{MnO} 3$ nanofibers for a high-temperature electrochemical carbon monoxide sensor," Nanotechnology, vol. 23, no. 30, 2012.

[18] C. Lin et al., "High Performance Colorimetric Carbon Monoxide Sensor for 
Continuous Personal Exposure Monitoring," ACS Sensors, vol. 3, no. 2, pp. 327-333, 2018.

[19] C. Pannek, K. R. Tarantik, K. Schmitt, and J. Wöllenstein, "Investigation of gasochromic rhodium complexes towards their reactivity to $\mathrm{CO}$ and integration into an optical gas sensor for fire gas detection," Sensors (Switzerland), vol. 18, no. 7, pp. 115, 2018.

[20] G. Alberti, M. Casciola, and R. Palombari, “Amperometric sensor for carbon monoxide based on solid state protonic conduction," Solid State Ionics, vol. 61, no. 13, pp. 241-244, 1993.

[21] C. T. Wang and M. T. Chen, "Vanadium-promoted tin oxide semiconductor carbon monoxide gas sensors," Sensors Actuators, B Chem., vol. 150, no. 1, pp. 360-366, 2010 .

[22] P. Van Geloven, M. Honore, J. Roggen, S. Leppavuori, and T. Rantala, "The influence of relative humidity on the response of tin oxide gas sensors to carbon monoxide," Sensors Actuators B. Chem., vol. 4, no. 1-2, pp. 185-188, 1991.

[23] M. Anastasescu et al., "Nanostructured $\mathrm{SnO} 2-\mathrm{ZnO}$ composite gas sensors for selective detection of carbon monoxide," Beilstein J. Nanotechnol., vol. 7, pp. 2045-2056, 2016.

[24] P. R. Patwardhan, J. A. Satrio, R. C. Brown, and B. H. Shanks, "Influence of inorganic salts on the primary pyrolysis products of cellulose," Bioresour. Technol., vol. 101, no. 12, pp. 4646-4655, 2010.

[25] Q. Lu, Z.-X. Zhang, X. Wang, H.-Q. Guo, M.-S. Cui, and Y.-P. Yang, "Catalytic Fast Pyrolysis of Biomass Impregnated with Potassium Phosphate in a Hydrogen Atmosphere for the Production of Phenol and Activated Carbon," Front. Chem., vol. 6, p. 32, Feb. 2018.

[26] L. Zhou, Y. Jia, T. Nguyen, A. A. Adesina, and Z. Liu, "Hydropyrolysis characteristics and kinetics of potassium-impregnated pine wood," Fuel Process. Technol., vol. 116, pp. 149-157, 2013.

[27] M. Safar et al., "Catalytic effects of potassium on biomass pyrolysis, combustion and 
torrefaction," Appl. Energy, vol. 235, pp. 346-355, 2019.

[28] K. Venkatesan, S. He, K. Seshan, P. Selvam, and R. Vinu, "Selective production of aromatic hydrocarbons from lignocellulosic biomass via catalytic fast-hydropyrolysis

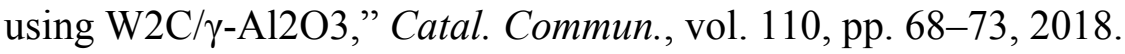

[29] M. A. Machado, S. He, T. E. Davies, K. Seshan, and V. Teixeira da Silva, "Renewable fuel production from hydropyrolysis of residual biomass using molybdenum carbidebased catalysts: An analytical Py-GC/MS investigation," Catal. Today, vol. 302, pp. 161-168, 2018.

[30] A. S. Al-Rahbi and P. T. Williams, "Waste ashes as catalysts for the pyrolysiscatalytic steam reforming of biomass for hydrogen-rich gas production," J. Mater. Cycles Waste Manag., 2019.

[31] A. Nyombi, M. R. Williams, and R. Wessling, "Mechanical impregnation of Pd$\mathrm{Sn} /$ alumina and $\mathrm{Cu}-\mathrm{Mn} /$ graphite on charcoal to minimise carbon monoxide emissions," Chem. Phys. Lett., vol. 715, pp. 181-185, Jan. 2019.

[32] R. W. A. Nyombi, M. Williams, "Reactivity and Free Radical Chemistry of Lilac (Syringa) Charcoal,” Energy \& Fuels, vol. 33, no. 2, pp. 1227-1235, 2019.

[33] R. García, C. Pizarro, A. G. Lavín, and J. L. Bueno, "Biomass proximate analysis using thermogravimetry," Bioresour. Technol., vol. 139, pp. 1-4, 2013.

[34] A. Nyombi, M. R. Williams, and R. Wessling, "Toxic emissions from smouldering combustion of woody biomass and derived char with a case study of CO build-up in an ISO container," Energy Sources, Part A Recover. Util. Environ. Eff., pp. 1-18, May 2019.

[35] L. Febrero, E. Granada, A. Regueiro, and J. L. Míguez, "Influence of Combustion Parameters on Fouling Composition after Wood Pellet Burning in a Lab-Scale LowPower Boiler,” Energies, vol. 8, pp. 9794-9816, 2015.

[36] Z. Wu, Z. Yu, W. Zhu, and R. Zhou, "Energy Saving and Pollution Reducing Effects of Coal Combustion Catalysts," Tsinghua Sci. Technol., vol. 6, no. 2, 2001.

[37] W. Hu, E. Marek, F. Donat, J. S. Dennis, and S. A. Scott, “A thermogravimetric method for the measurement of $\mathrm{CO} / \mathrm{CO} 2$ ratio at the surface of carbon during 
combustion,” Proc. Combust. Inst., vol. 37, no. 3, pp. 2987-2993, 2019.

[38] M. Morin, S. Pécate, and M. Hémati, "Kinetic study of biomass char combustion in a low temperature fluidized bed reactor," Chem. Eng. J., vol. 331, no. August, pp. 265$277,2018$.

[39] K. B. Larionov and A. A. Gromov, "Non-isothermal oxidation of coal with $\mathrm{Ce}(\mathrm{NO} 3) 3$ and $\mathrm{Cu}(\mathrm{NO} 3) 2$ additives," Int. J. Coal Sci. Technol., vol. 6, no. 1, pp. 37-50, 2019.

[40] Y. J. Rueda-Ordóñez and K. Tannous, "Isoconversional kinetic study of the thermal decomposition of sugarcane straw for thermal conversion processes," Bioresour. Technol., vol. 196, pp. 136-144, 2015.

[41] Q. Zheng, R. Farrauto, and M. Deeba, "Part II: Oxidative Thermal Aging of Pd/A12O3 and $\mathrm{Pd} / \mathrm{CexOy}-\mathrm{ZrO} 2$ in Automotive Three Way Catalysts: The Effects of Fuel Shutoff and Attempted Fuel Rich Regeneration,” Catalysts, vol. 5, no. Part II, pp. 1797-1814, 2015.

[42] P. Glarborg, J. A. Miller, B. Ruscic, and S. J. Klippenstein, "Modeling nitrogen chemistry in combustion," Prog. Energy Combust. Sci., vol. 67, pp. 31-68, 2018.

[43] J. Leppdahti and T. Koljonen, "Review Nitrogen evolution from coal, peat and wood during gasification : Literature review," Fuel Process. Technol., vol. 43, pp. 1-45, 1995.

[44] S. Fournel, J. H. Palacios, S. Godbout, and M. Heitz, "Effect of Additives and Fuel Blending on Emissions and Ash-Related Problems from Small-Scale Combustion of Reed Canary Grass,” Agriculture, vol. 5, no. x, pp. 561-576, 2015. 